\title{
Five-year soil moisture response of typical cultivated grasslands in a semi-arid area: Implications for vegetation restoration
}

\author{
Zhi-Qiang Dang ${ }^{1, \S}$, Ze Huang ${ }^{1, \S}$, Fu-Ping Tian ${ }^{2}$, Yu Liu${ }^{1}$, Manuel López-Vicente ${ }^{3}$, Gao-Lin Wu ${ }^{1,4, *}$ \\ ${ }^{1}$ State Key Laboratory of Soil Erosion and Dryland Farming on the Loess Plateau, Institute of Water and Soil \\ Conservation, Northwest A\&F University, Yangling, Shaanxi, China \\ ${ }^{2}$ Lanzhou Institute of Husbandry and Pharmaceutical Sciences of Chinese Academy of Agricultural Sciences, \\ Lanzhou, Gansu 730050 China \\ ${ }^{3}$ Genetics, Genomics and Breeding of Fruits and Grapevine Laboratory, Department of Pomology, Experimental \\ Station of Aula Dei, EEAD-CSIC, Zaragoza 50059, Spain \\ ${ }^{4}$ CAS Center for Excellence in Quaternary Science and Global Change, Xi'an, 710061, China \\ $\S$ These authors contributed equally to this work and are co-first authors. \\ * Corresponding author e-mails: wugaolin@nwsuaf.edu.cn (G.L.Wu)
}

Post address: State Key Laboratory of Soil Erosion and Dryland Farming on the Loess Plateau, Institute of Soil and Water Conservation, Chinese Academy of Sciences / Northwest A\&F University, NO. 26 Xinong Road, Yangling, Shaanxi Province 712100, Peoples Republic of China.

Received: 5 September 2019 | Revised: 15 December 2019 | Accepted: 24 December 2019 | First published in Wiley Online Library: 30 December 2019. I https://doi.org/10.1002//dr.3537 Land Degradation \& Development Volume 31, Issue 9 (30 May 2020), Pages 1078-1085.

\begin{abstract}
Soil water deficit is one of the important abiotic stresses affecting vegetation restoration. The magnitude and spatiotemporal dynamics of soil water content (SWC) provide basic guidance for optimal vegetation restoration. In a semiarid Chinese area, the changes in the soil water storage (SWS) of five cultivated grasslands and one wasteland were observed, to evaluate the water consumption at different soil depths $(0-100 \mathrm{~cm})$, from 2008 to 2012 . The plants of the three leguminous species consumed more water in deep soil layers $(80-100 \mathrm{~cm})$ and produced more aboveground biomass than the plants of the two gramineous species. The gramineous plants mainly consumed shallow soil water $(0 \leq 30 \mathrm{~cm})$. The soil water deficit in the whole soil profile of Medicago sativa grassland (43-48\%) was significantly higher than the deficit of the gramineous grasslands ( $p$ $<.05)$. After 5 years of planting, the SWC of Agropyron cristatum grassland (21\%) was the highest in the 20 - to $80-\mathrm{cm}$ soil layer. The variation of SWS in M. sativa grassland did not significantly differ during this period, although its mean value was $28 \%$ lower than the value in $A$. cristatum grassland
\end{abstract}


$(181 \mathrm{~mm})$. At the end of the experiment, leguminous grasslands caused a serious soil water shortage deficit in the 80 - to $100-\mathrm{cm}$ soil layers. These results underscore that vegetation type determines the vertical distribution of soil water deficit, particularly in deep layers. To promote long-term sustainability of water resources, planting A. cristatum may be a good choice for early grassland restoration in arid areas.

KEY WORDS: arid area, grassland restoration, soil water content, soil water deficit degree

\section{INTRODUCTION}

Vegetation restoration is one of the most important and effective way to reduce soil and water loss (Yu et al., 2015). The restoration of natural grasslands and the establishment of artificial grasslands are common practices in the arid areas of the world. In these landscapes, and during the process of restoration, the soil water content (SWC) is the key limiting factor for vegetation growth (Siltecho et al., 2015; Wang, Li, Xiao, Berndtsson, \& Pan, 2007; Wang, Fan, Cao, \& Liang, 2016). Soil water is not only the basis for plant survival in terrestrial ecosystem, but also the most active part within the watershed water cycle because it affects plant growth, ecological environment construction and the rational distribution and efficient utilization of water resources. In semi-arid regions, the current global warming is aggravating drought conditions by increasing the potential evapotranspiration (Muluneh, Biazin, Stroosnijder, Bewket, \& Keesstra, 2015).

Previous studies have indicated that the different species cultivated in grasslands play an important role in the observed values of the soil hydraulic parameters (Mao and Cherkauer, 2009; Gonzalez-Sosa et al., 2010). Different cultivated grasslands have critical influence on soil water variation (Huang et al., 2018). In arid regions, grassland sustainability is commonly associated with the soil water availability (Liu, Chen, \& Xu, 2010; Rodriguez-Iturbe, 2000). Leguminous plants can be used to increase grassland above-ground biomass (Wu, Liu, Tian, \& Shi, 2017) and community diversity (Daniel, Robert, \& Roch, 1999), as well as to improve soil structure (Lal, 1996). However, the high water consumption of leguminous species has become the main limiting factor for their popularization in arid areas. In particular, the soil in Medicago sativa grasslands can be severely, even extremely, desiccated over planting time (Cui et al., 2018). On the other hand, the different grassland species have distinct canopy structure, soil cover rates and root distribution that may result in the modification of the soil properties and thus affecting soil water infiltration (Angers and Caron, 1998; Bormann and Klaassen, 2008; Vervoort, Dabney, \& Römkens, 2001; Wang, Li, Xiao, Berndtsson, \& Pan, 2007; Yu et al., 2015; Zhao, Wu, Zhao, \& Feng, 2013). Fan et al. (2010) observed that the root biomass in the $0-10 \mathrm{~cm}$ soil layer accounted for $65.9 \%-82.6 \%$ of the total biomass in the $0-40 \mathrm{~cm}$ soil layer and the characteristics of the root distribution had certain feedback on the soil physicochemical properties.

The maintenance of a certain level of above-ground biomass is essential for improving 
ecological indicators in restored landscapes. At the same time, higher biomass implies a higher consumption of soil water. Thus, trade-off the relationship between biomass and soil water content is necessary to achieve a sustainable vegetation restoration. The main objectives of this study were to characterize and evaluate the variation of the above-ground biomass and soil water content in different grasslands under semi-arid conditions. The relationships between them were explored to choose the most suitable species for the sustainable development of grassland restoration. We explored the relationships between the above-ground biomass and the soil water storage deficit with the increase of planting years. First, we determined the time series changes of SWC in five different grasslands along the soil profile $(0-100 \mathrm{~cm}$ depth) and the above-ground biomass during a five-year period, from 2008 to 2012. Then, the relationships between the above-ground biomass and the soil water storage deficit were analyzed with the increase of the planting age. Finally, these results were compared with the observed dynamics in a wasteland that acted as control area. The findings and conclusions of this study can provide an evidence for selecting proper grass species to build artificial grassland in semi-arid regions.

\section{MATERIALS AND METHODS}

\subsection{Study sites}

This study was conducted in the Regional Experimental Station of Lanzhou Institute of Animal Husbandry and Veterinary Medicine, Chinese Academy of Agricultural Sciences, which is located in Lanzhou city, Gansu Province, China $\left(36^{\circ} 01^{\prime} \mathrm{N}, 103^{\circ} 45^{\prime} \mathrm{W}\right)$. This area belongs to the semi-arid and gully canal hilly area within the western Loess Plateau. The main soil type is calcareous loess and the soil water content at field capacity is about $19.3 \%$ volume. The soil parent material is quaternary aeolian loess, which is characteristic of the Chinese loess region (Li, Zhao, Song, \& Zhu, 2010). The average altitude of the test site is $1,732 \mathrm{~m}$ a.s.I. In this area, the native grassland ecosystem is mainly dominated by Stipa capillata. During the growing season of the test period (2008-2012), from April to September, the mean maximum and minimum temperature was $23.1^{\circ} \mathrm{C}$ and $9.8^{\circ} \mathrm{C}$, respectively; and the mean annual precipitation was $324.5 \mathrm{~mm}$, most of them recorded between July and September. The average annual evaporation is about $1450.0 \mathrm{~mm}$ and the sunshine duration is $2651.4 \mathrm{~h}$.

\subsection{Experimental design}

The experimental site was planted with sorghum (Sorghum bicolor L.) continuously from 1970 to 2005 and was abandoned from 2005 to 2007 (grazing was excluded). Then, we selected five cultivated grasslands and one abandoned cropland (natural successional species were present, e.g., Chenopodium album L. and Agropyron cristatum L.) where we established the study site. Five main forage grasses, widely grown across arid areas, were selected and cultivated, including three leguminous species (Medicago sativa L., so-called "A"; Onobrychis viciifolia Scop, so-called "B"; and Coronilla varia L., so-called "C") and two gramineous species (Poa pratensis L., so-called "D"; and 
Agropyron cristatum L. Gaertn., so-called "E"). Besides, one abandoned cropland (so-called "F") was added as control plot. According to the different sowing rates of the various herbage, the five grasslands were planted in early April 2007. We designed the experiment following a randomized plot design. Three experimental plots $(10 \mathrm{~m} \times 20 \mathrm{~m})$ were established randomly within each grassland area. During the planting, the criteria for seed density followed the local farmers experience for many years. All plots were weeded manually to remove unplanted species and no irrigation was applied from 2008 to 2012. These plots were not fertilized during planting. The five annual surveys to measure the SWC and aboveground biomass were conducted in the same month, in August, in order to obtain comparable data.

\subsection{Soil sampling and measurements}

The roots of the grass are mainly distributed in the $0-100 \mathrm{~cm}$ soil layers. Thus, the SWC in the $0-100$ $\mathrm{cm}$ soil layers were measured. Soil samples were collected every $10 \mathrm{~cm}$ intervals up to a maximum depth of $100 \mathrm{~cm}$ by using a 4-cm diameter soil auger. In each plot, three samples were randomly collected and three soil cores were randomly taken with a stainless cylinder for assays of soil water. A total of 900 soil samples were taken and carried into the laboratory. All soil samples were weighed immediately after their collection, then dried at $105^{\circ} \mathrm{C}$ for $24 \mathrm{~h}$, and finally weighed again. A 5-cm diameter and $5-\mathrm{cm}$ high stainless-steel cutting ring (ca. $100 \mathrm{~cm}^{3}$ ) was used to estimate the soil bulk density (BD) at adjacent points to the soil sampling points. The BD was also measured every $10 \mathrm{~cm}$ intervals up to a maximum depth of $100 \mathrm{~cm}$ and then averaged to obtain the mean value of the soil profile.

\subsection{AGB estimation}

Five quadrats of $1.0 \mathrm{~m}^{2}(1.0 \mathrm{~m} \times 1.0 \mathrm{~m})$ were randomly set up in each plot in late August every year (2008-2012). The above-ground biomass (AGB) was estimated after cutting the plant stems at the soil surface level and then sealed in labeled sealing bags. Each sample was weighed while the plant material was fresh and then re-weighed after drying at $65^{\circ} \mathrm{C}$ to a constant weight.

\subsection{Assessment of SWS and deficit}

The BD was calculated based on the oven-dried weight of the composite soil samples (Deng et al., 2013). The soil water storage (SWS) was calculated for all samples collected at each grassland site using the approach of Gao et al. (2014):

$$
S W S=h \cdot \rho \cdot \vartheta \cdot 10^{-1}
$$

where $h$ is the soil depth $(\mathrm{cm}), \rho$ is the soil bulk density $\left(\mathrm{g} \mathrm{cm}^{-3}\right)$, and $\vartheta$ is the gravimetric soil water content (\% weight). 
The soil water storage deficit degree (SWSD) was calculated as follows (Wang, Huang, \& Lou, 2004):

$$
\begin{aligned}
& \text { SWSD }=D a / F C \times 100 \% \\
& D a=F C-W
\end{aligned}
$$

where $D a$ is the soil water storage deficit $(\mathrm{mm})$, and $F c$ is the soil water content at field capacity $(\mathrm{mm})$. The $F c$ was determined by means of the ring knife method.

\subsection{Statistical analyses}

Two-way analysis of variance (ANOVA) was used to assess the effects of planting years, grass species and their interactions on the soil water storage and above-ground biomass. Significant differences were evaluated by using Tukey's honestly significant difference (HSD) test at the 0.05 level. All data analysis was done by using SPSS 18.0 software (SPSS, 2009). Regression lines were plotted to express the relationships between the soil water storage $(0-100 \mathrm{~cm})$ and above-ground biomass. Data in the results were expressed as mean values \pm standard deviation $(M \pm S D)$. The figures were plotted by using Origin Pro 9.1 software.

\section{RESULTS}

\subsection{Variations of SWC after five planting years}

The SWC in the five artificial grasslands and the abandoned cropland clearly varied between them and along the different soil depths (Fig. 1). The lowest SWC was found in the soil layers at 0 and 30 $\mathrm{cm}$ soil depth in the $O$. viciifolia grassland. In the whole analyzed soil profile $(0-100 \mathrm{~cm})$, the SWC of the three leguminous grasslands was lower than that of the gramineous grasslands. In particular, in the $M$. sativa grassland the SWC was always very low and the observed high-water consumption of the deep soil water could possibly trigger soil desiccation. Along the soil profile, in the range of 0-100 $\mathrm{cm}$, the water deficit of alfalfa grassland was the largest and this deficit decreased with increasing the soil depth. Conversely, the SWC was relatively high in the P. pratensis and A. cristatum grasslands. Related to the planting years, the SWC of the two gramineous grasslands increased with increasing the age.

\subsection{Annual variations of SWS and AGB}

The statistical analysis showed that the grassland type had significant effects on the SWS and ABG (P $<0.01$ ), while the effects of planting year was not significant $(P>0.05$, Table 1$)$. The grassland type and year interaction was significant in the SWS and ABG $(P<0.01)$. The SWS of the leguminous grasslands at 0-100 $\mathrm{cm}$ soil layers was lower than that of the gramineous grasslands (Fig. 2). During the 5 -year test period, the lowest value of the SWS was observed in the 0 . viciifolia grassland (138.51 
$\pm 0.99 \mathrm{~mm}$ ) in $2009(\mathrm{p}<0.05)$, and the highest SWS value appeared in the A. cristatum grassland $(185.45 \pm 1.90 \mathrm{~mm})$ in $2010(p<0.05)$. However, the SWS had no significant difference during the five years in the $M$. sativa grassland and its average value was about $28 \%$ lower than the average SWS in the $A$. cristatum grassland.

On average, the AGB of the $M$. sativa grassland $\left(27,438.73 \pm 12,704.94 \mathrm{~kg} \mathrm{hm}^{-2}\right)$ was higher than the AGB in the other grasslands (Fig. 3). The abandoned cropland presented the lowest average AGB value $\left(5,206.41 \pm 1,722.37 \mathrm{~kg} \mathrm{hm}^{-2}\right)$. From the total measurements, the highest AGB appeared in the M. sativa grassland $\left(42,225 \pm 888.53 \mathrm{~kg} \mathrm{hm}^{-2}\right)$ in 2012 , and this values was significantly different from the AGB of the other grasslands $(p<0.05)$. After the five planting years, the average AGB of the leguminous grasslands was much higher than the AGB of the gramineous grasslands, although their average soil water storage (SWS) was lower (Fig. 4). The maximum average SWS was observed in the A. cristatum grassland (179.31 $\pm 6.02 \mathrm{~mm})$, and this difference was statistically significant with regard to the other grasslands $(p<0.05)$.

\subsection{Relationships between the AGB and SWSD}

The evolution of the AGB described a parabolic curve, whereas the evolution of the soil water storage deficit (SWSD) showed a continuous downward trend over the planting time (Fig. 5). The AGB curve of the $M$. sativa grassland described a continuous rise and the degree of its SWSD was very large $\left(>43 \%, R^{2}=0.79\right)$. On the other side, the SWSD was minimum $\left(<32 \%, R^{2}=0.74\right)$ in the $A$. cristatum grassland. In all grasslands, the highest levels of the SWSD were obtained at the third year after sowing. During the test-period, the AGB was firstly reduced and then increased in the abandoned cropland and the maximum value appeared in the fourth year after sowing.

\section{DISCUSSION}

In the present study, we explored the relationship between the above-ground biomass and soil water storage deficit in five different cultivated grasslands and one abandoned cropland. Water is one of the important components of plants. The survival, growth, development and reproduction of plants cannot be separated from water. In semi-arid areas, with low rainfall and high evaporation, soil water is an important way of water absorption in plants. In this experiment, strong water consumption caused the highest SWSD on the M. sativa grassland. This species has a strong root system, which can use shallow and deep soil moisture, and then, affected the redistribution of soil water content and soil moisture. Plants with large leaf area, high yield and deep roots consume more soil water (Cheng, Huang, Shao, \& Warrington, 2009). With the growth of M. sativa the water demand increased and the soil moisture of shallow and deep layers decreased. It is known that $M$. sativa is a kind of plant with high water consumption requirements and it can even absorb water from deep soil layers by using its extensive root system (Cui et al., 2018). Previous studies have found that, with increasing the age of alfalfa grassland, the main soil depth where water consumption was predominant was 
gradually deepening (Ren, Li, Wang, \& Fang, 2011). On the other hand, A. cristatum and abandoned cropland only consumed shallow soil water and this fact was related to the biological characteristics of the vegetation. A. cristatum and the grass on the abandoned cropland have an elongated blade and a thicker stratum corneum, which reduced the amount of transpiration. A. cristatum has formed a series of physiological and ecological mechanisms to resist drought stress because it has survived in dry environments for a long time. Under natural conditions, Singh, Milchunas, et al. (1998) observed that the change of water content in deeper soil layers was smaller than in topsoil and can be used as a potential resource, which can buffer the influence of precipitation and keep the vegetation stability of the grass community. The average SWC value in the leguminous grasslands was lower than that in the gramineous grasslands. The utilization of shallow water was particularly prominent in $M$. sativa grassland. Many studies have shown that leguminous plants consume more water than gramineous plants in arid and semi-arid areas (Cui et al., 2018; Huang et al., 2018). Other studies have indicated that the roots of the leguminous plants ( $C$. korshinskii and $M$. sativa) were deeply distributed and could consume more deep soil water (Huang et al., 2017; Jia and Shao, 2013). Previous studies showed that the differences of SWC among different soil profiles and grasslands were mainly affected by the root distribution and depth (Cheng, Huang, Shao, \& Warrington, 2009; Schenk and Jackson, 2002; Yang, Wei, Chen, Chen, \& Wang, 2014). Deep-root plants are high water-consumption plants that can use deep soil water, while plants with fiber roots are relatively low-water consumption plants (Jia and Shao, 2013; Pelaez, Distel, Boo, Elia, \& Mayor, 1994; Zhao, Jia, Zhu, \& Shao, 2017). Therefore, a large amount of deep soil water was used in the M. sativa grassland and a small amount of deep soil water was used in the $A$. cristatum grassland and abandoned cropland.

The lack of soil moisture affects dry matter yield of grassland and this may be related to the growth of cultivated species, root characteristics and transpiration. The soil water deficit did not always reduced the dry matter yield and a large amount of soil water was consumed and converted into dry matter yield in the $M$. sativa grassland. The gramineous grassland had a low dry matter weight. The statistical test showed that the grassland type had significant effects on the ABG $(P<$ $0.01)$, while the effects of planting year were not significant $(P>0.05)$. The evolution of the $A G B$ described a parabolic curve, whereas the evolution of the soil water storage deficit (SWSD) showed a continuous downward trend over the planting time. With the change of planting year, the AGB was also changing. The effect of soil water shortage on grassland biomass was more obvious. On the other hand, it was indicated that the variety of plants was different to the degree of water utilization. Some of the results were similar to those of previous studies. Grasslands with gramineous plants have fiber roots in deep soil layers and the distribution of underground biomass is limited, thus reducing the consumption of soil water (Ruiz-Sinoga et al., 2011). In arid areas, grasslands with leguminous plants have deep main roots that need more water during the growing season, which tend to dry the whole soil profile and reduce the water supply (Xu, Gichuki, Shan, \& Li, 2006). In this study, field observations showed that the time stability of SWC increased with increasing the soil depth. This finding was consistent with the results of Fu, Wang, et al. (2003) and Liu and Shao (2014), who found that the SWC of deeper soil layers was relatively stable despite the seasonal variation. 
The soil water storage is an important index of water resources and the basis of vegetation planting, especially in arid areas (Zhao, Jia, Zhu, \& Shao, 2017). The SWS in the M. sativa grassland did not significantly vary during the five-year test period, although it was about $28 \%$ lower than the SWS in the A. cristatum grassland (181 mm). Soil water is consumed by evaporation and transpiration. The distribution model of soil water is related to the AGB, root biomass and plant species distribution. High yield requires more water and the presence of deep roots that absorb deeper soil water; and the different plant species have different transpiration rates (Siltecho et al., 2015; Wang, Li, Xiao, Berndtsson, \& Pan, 2007; Wang, Fan, Cao, \& Liang, 2016). Previous studies have suggested that the root system of the leguminous grasslands was deeper, which resulted in a higher consumption of soil water than the consumption of the gramineous grasslands (Huang et al., 2018). This process could further aggravate the soil water deficit and hinder the sustainability of field grasslands. Although the AGB of the leguminous grasslands was the highest in this study, more specific studies are still needed to determine the potential mechanism of water consumption in each plant. Therefore, in order to give full play to the characteristics of species, it is necessary to deeply study its ecological effects in future.

\section{CONCLUSIONS}

The AGB and soil water response (content and storage deficit) of five different cultivated grasslands were compared and analyzed by long-term field measurements obtaining significant differences among them. The vegetation type clearly determined the predominant depth of the soil water deficit and its vertical distribution under semiarid conditions. The AGB in the leguminous grasslands ( $M$. sativa L., O. viciifolia Scop, and C. varia L.) was higher than in the gramineous grasslands (P. pratensis L., and A. cristatum L. Gaertn.). A large amount of soil water was consumed by the $M$. sativa plants, whereas the largest SWS appeared in the A. cristatum grassland. Compared with the other grasslands, the best soil water status was observed in the $A$. cristatum grassland. Therefore, planting $A$. cristatum as a pioneer grass species appears as a good choice for long-term vegetation restoration in semiarid areas.

\section{ACKNOWLEDGEMENTS}

We thank the editor $\mathrm{Dr}$ Joris de Vente and reviewers for their constructive comments and suggestions on this work. This research was funded by the National Natural Science Foundation of China (NSFC 41722107, 41977063, 41930755), the Key R \& D Program of Shaanxi Province (2017NY-065), and the Agricultural Science and Technology Innovation Program of the Chinese Academy of Agricultural Sciences (CAAS-ASTIP-2016-LIHPS-08). 
Yu Liu: https://orcid.org/0000-0003-0706-4026

Manuel López-Vicente: https://orcid.org/0000-0002-6379-8844

Gao-Lin Wu: https://orcid.org/0000-0002-5449-7134

\section{REFERENCES}

Angers, D. A., \& Caron, J. (1998). Plant-induced changes in soil structure: processes and feedbacks. Biogeochemistry, 42, 55-72. https://doi.org/ 10.1023/A:1005944025343

Bormann, H., \& Klaassen, K. (2008). Seasonal and land use dependent variability of soil hydraulic and soil hydrological properties of two Northern German soils. Geoderma, 145, 295-302. https://doi.org/ 10.1016/j.geoderma.2008.03.017

Cheng, X. R., Huang, M. B., Shao, M. A., \& Warrington, D. N. (2009). A comparison of fine root distribution and water consumption of mature Caragana korshinkii Kom grown in two soils in a semiarid region, China. Plant and Soil, 315, 149-161. https://doi.org/ 10.1007/s11104-008-9739-5

Cui, Z., Liu, Y., Jia, C., Huang, Z., He, H., Han, F., Shen, W., Wu, G. L. (2018). Soil water storage compensation potential of herbaceous energy crops in semi-arid region. Field Crops Research, 223, 41-47. https://doi.org/10.1016/j.fcr.2018.03.026

Daniel, D. B., Robert, A. M., \& Roch, E. G. (1999). Grassland legume establishment with imazethapyr and imazapic. Agronomy Journal, 91, 592-596. https://doi.org/ 10.2134/agronj1999.914592x

Deng, L., Shangguan, Z. P., \& Sweeney, S. (2013). Changes in soil carbon and nitrogen following land abandonment of farmland on the Loess Plateau, China. PLOS ONE, 8, e71923. https://doi.org/ 10.1371/journal.pone.0071923

Fan, G. Y. , Zhang, J. N. , Zhang, Y. S. , Li, G., Wang, Q., \& Yang, D. L. (2010). Effects of grazing on plant root distribution and soil physicochemical properties in Stipa baicalensis grassland. Chinese Journal of Ecology, 29, 1715-1721. (in China)

Fu, B. J., Wang, J., Chen, L. D., \& Qiu, Y. (2003). The effects of land use on soil moisture variation in the Danangou catchment of the Loess Plateau, China. Catena, 54, 197-213. https://doi.org/10.1016/S0341-8162(03)00065-1

Gao, Y., Fan, J., Peng, X. P., Wang, L., \& Mi, M. X. (2014). Soil water depletion and infiltration under the typical vegetation in the water-wind erosion crisscross region. Acta Ecologica Sinica, 34, 7038-7046. (in China)

Gonzalez-Sosa, E., Braud, I., Dehotin, J., Lassabatère, L., Angulo-Jaramillo, R., Lagouy, M., ... Michel, K. (2010). Impact of land use on the hydraulic properties of the topsoil in a small French catchment. Hydrological Processes, 24, 2382-2399. https://doi.org/10.1002/hyp.7640 
Hobbie, S. E., Ogdahl, M., Chorover, J., Chadwick, O. A., Oleksyn, J., Zytkowiak, R., \& Reich, P. B. (2007). Tree species effects on soil organic matter dynamics: the role of soil cation composition. Ecosystems, 10, 999-1018. https://doi.org/ 10.1007/s10021-007-9073-4

Huang, Z., Miao, H. T., Liu, Y., Tian, F. P., He, H. H., Shen, W. B., ... Wu, G. L. (2018). Soil water content and temporal stability in an arid area with natural and planted grasslands. Hydrological Processes, 32, 3784-3792. https://doi.org/ 10.1002/hyp.13289

Huang, Z., Tian, F. P., Wu, G. L., Liu, Y., \& Dang, Z. Q. (2017). Legume grasslands promote precipitation infiltration better than gramineous grasslands in arid regions. Land Degradation \& Development, 28, 309-316. https://doi.org/ 10.1002/ldr.2635

Jia, Y. H., \& Shao, M. A. (2013). Temporal stability of soil water storage under four types of revegetation on the northern Loess Plateau of China. Agricultural Water Management, 117, 33-42. https://doi.org/ 10.1016/j.agwat.2012.10.013

Köchy, M., Don, A., van der Molen, M. K., \& Freibauer, A. (2015). Global distribution of soil organic carbon-Part 2: Certainty of changes related to land use and climate. Soil, 1, 367-380. https://doi.org/ 10.5194/soil-1-367-2015

Lal, R. (1996). Deforestation and land-use effects on soil degradation and rehabilitation in western Nigeria. I. Soil physical and hydrological properties. Land Degradation \& Development, 7, 19-45.

Li, J., Zhao, C. Y., Song, Y., \& Zhu, H. (2010). Spatial patterns of desert annuals in relation to shrub effects on soil moisture. Journal of Vegetation Science, 21, 221-232. https://doi.org/ 10.1111/j.1654-1103.2009.01135.x

Liu, C. M., Chen, Y. N., \& Xu, Z. X. (2010). Eco-hydrology and sustainable development in the arid regions of China preface. Hydrological Processes, 24, 127-128. https://doi.org/ 10.1002/hyp.7481

Liu, B. X., \& Shao, M. A. (2014). Estimation of soil water storage using temporal stability in four land uses over 10 years on the Loess Plateau, China. Journal of Hydrology, 517, 974-984. https://doi.org/ 10.1016/j.jhydrol.2014.06.003

Lucero, D. W., Grieu1, P., \& Guckert, A. (2000). Water deficit and plant competition effects on growth and water-use efficiency of white clover (Trifolium repens, L.) and ryegrass (Lolium perenne, L.). Plant and Soil, 227, 1-15. https://doi.org/10.1023/A:1026560128042

Mao, D., \& Cherkauer, K. A. (2009). Impacts of land-use change on hydrologic responses in the Great Lakes region. Journal of Hydrology, 374, 71-82. https://doi.org/ 10.1016/j.jhydrol.2009.06.016

Muluneh, A., Biazin, B., Stroosnijder, L., Bewket, W., \& Keesstra, S. (2015). Impact of predicted changes in rainfall and atmospheric carbon dioxide on maize and wheat yields in the Central Rift Valley of Ethiopia. Regional Environmental Change, 15, 1105-1119. https://doi.org/ 10.1007/s10113-014-0685-x 
Pelaez, D. V., Distel, R. A., Boo, R. M., Elia, O. R., \& Mayor, M. D. (1994). Water relations between shrubs and grasses in semi-arid Argentina. Journal of Arid Environments, 27, 71-78. https://doi.org/ 10.1006/jare.1994.1046

Ren, J. J., Li, J., Wang, X. C., \& Fang, X. Y. (2011). Soil water and nutrient characteristics of alfalfa grasslands at semi-arid and semi-arid prone to drought areas in southern Ningxia. Acta Ecologica Sinica, 31, 3638-3694. (in China)

Rodriguez-Iturbe, I. (2000). Ecohydrology: A hydrologic perspective of climate-soil-vegetation dynamics. Water Resources Research, 36, 3-9. https://doi.org/ 10.1029/1999WR900210

Ruiz-Sinoga, J. D., Galeote, M. A. G., Murillo, J. F. M., \& Marín, R. G. (2011). Vegetation strategies for soil water consumption along a pluviometric gradient in southern Spain. Catena, 84, 12-20. https://doi.org/ 10.1016/j.catena.2010.08.011

Schenk, H. J., \& Jackson, R. B. (2002). Rooting depths, lateral root spreads and below-ground / above-ground allometries of plants in water-limited ecosystems. Journal of Ecology, 90, 480-494. https://doi.org/ 10.1046/j.1365-2745.2002.00682.x

Siltecho, S., Hammecker, C., Sriboonlue, V., Clermont-Dauphin, C., Trelo-Ges, V., Antonino, A. C. D., \& Angulo-Jaramillo, R. (2015). Use of field and laboratory methods for estimating unsaturated hydraulic properties under different land uses. Hydrology and Earth System Sciences, 19, 1193-1207. https://doi.org/ 10.5194/hess-19-1193-2015

Singh, J. S. D., Milchunas, G., \& Lauenroth, W. K. (1998). Soil water dynamics and vegetation patterns in a semiarid grassland. Plant Ecology, 134, 77-89. https://doi.org/ 10.1023/A:1009769620488

SPSS. (2009). PASW statistics for windows, version 18.0. SPSS Inc., Chicago.

Vervoort, R. W., Dabney, S. M., \& Römkens, M. J. M., 2001. Tillage and row position effects on water and solute infiltration characteristics. Soil Science Society of America Journal, 65, 1227-1234. https://doi.org/ 10.2136/sssaj2001.6541227x

Wang, X. P., Li, X. R., Xiao, H. L., Berndtsson, R., \& Pan, Y. X. (2007). Effects of surface characteristics on infiltration patterns in an arid shrub desert. Hydrological Processes, 21, 72-79. https://doi.org/ 10.1002/hyp.6185

Wang, Y., Fan, J., Cao, L., \& Liang, Y. (2016). Infiltration and runoff generation under various cropping patterns in the red soil region of China. Land Degradation \& Development, 27, 83-91. https://doi.org/ 10.1002/ldr.2460

Wang, J. X., Huang, B. L., \& Lou, W. X. (2004). Compensation and rehabilitation characteristics of soil water deficit at a planted forest site of the drought-prone Loess Plateau. Acta Ecologica Sinica, 24, 2395-2401. (in China)

Wu, G. L., Liu, Y., Tian, F. P., \& Shi, Z. H. (2017). Legumes functional group promotes soil organic 
carbon and nitrogen storage by increasing plant diversity. Land Degradation \& Development, 28 , 1336-1344. https://doi.org/ 10.1002/ldr.2570

Xu, B. C., Gichuki, P., Shan, L. \& Li, F. M. (2006). Aboveground biomass production and soil water dynamics of four leguminous forages in semiarid region, Northwest China. South African Journal of Botany, 72, 507-516. https://doi.org/ 10.1016/j.sajb.2006.01.005

Yang, L., Wei, W., Chen, L. D., Chen, W. L., \& Wang, J. L. (2014). Response of temporal variation of soil moisture to vegetation restoration in semi- arid Loess Plateau, China. Catena, 115, 123-133. https://doi.org/ 10.1016/j.catena.2013.12.005

Yu, M. Z., Zhang, L. L., Xu, X. X., Feger, K. H., Wang, Y. H., Liu, W. Z., \& Schwarzel, K. (2015). Impact of land-use changes on soil hydraulic properties of Calcaric Regosols on the Loess Plateau, NW China. Journal of Plant Nutrition and Soil Science, 178, 486-498. https://doi.org/ 10.1002/jpln.201400090

Zhao, Y. G., Wu, P. T., Zhao, S. W., \& Feng, H. (2013). Variation of soil infiltrability across a 79-year chronosequence of naturally restored grassland on the Loess Plateau, China. Journal of Hydrology, 504, 94-103. https://doi.org/10.1016/j.jhydrol.2013.09.039

Zhao, C. L., Jia, X. X., Zhu, Y. J., \& Shao, M. A. (2017). Long-term temporal variations of soil water content under different vegetation types in the Loess Plateau, China. Catena, 158, 55-62. https://doi.org/10.1016/j.catena.2017.06.006 
FIGURE 1. Time series changes of soil water content (SWC) in the different grassland types in 0- to $100-\mathrm{cm}$ soil depth at $10-\mathrm{cm}$ intervals, from 2008 to 2012. The grassland types are (a) (Medicago sativa), (b) (Onobrychis viciifolia), (c) (Coronilla varia), (d) (Poa pratensis), (e) (Agropyron cristatum), and (f) (abandoned cropland).

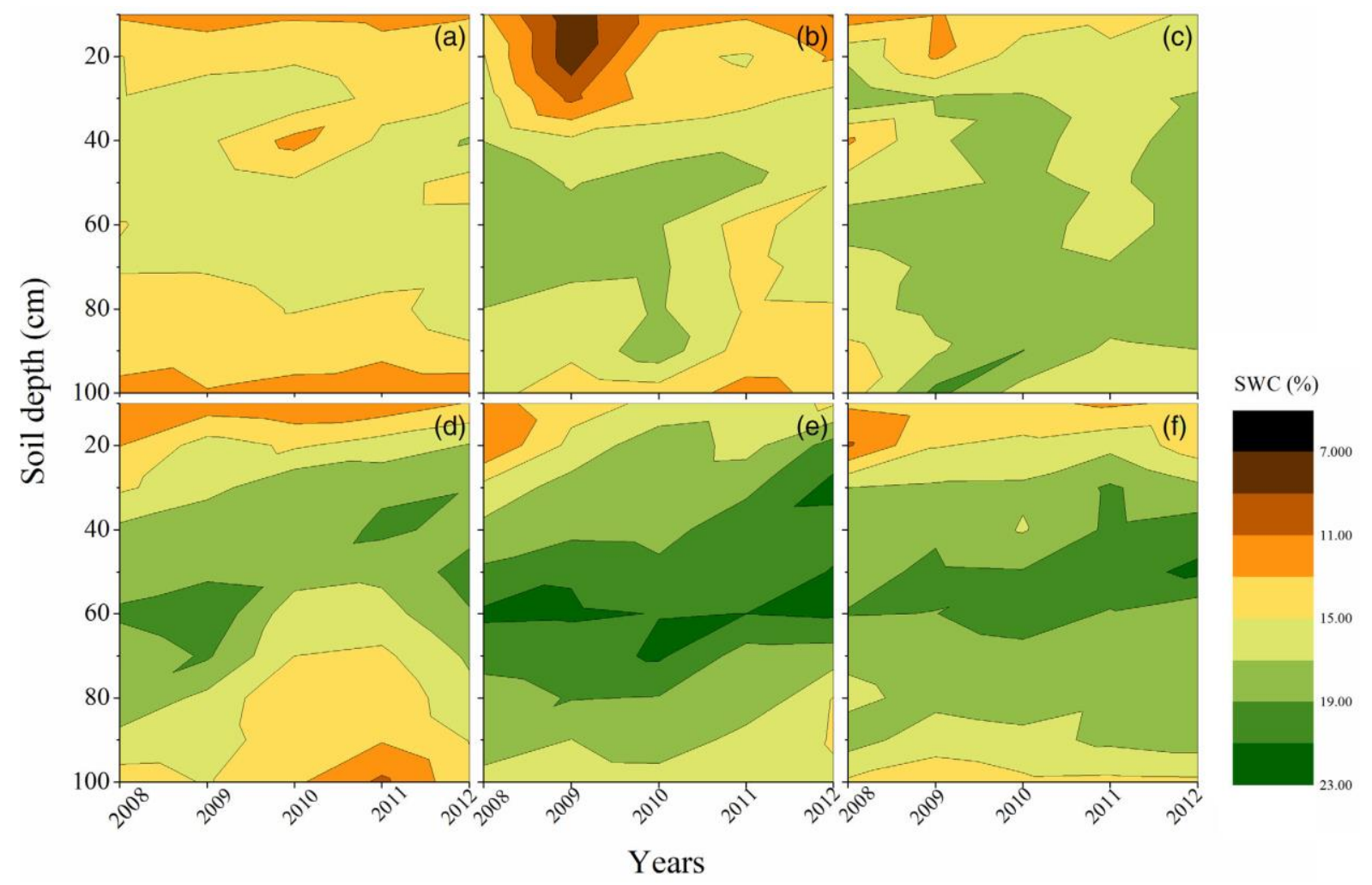


FIGURE 2. Soil water storage (SWS) variation on $0-$ to $100-\mathrm{cm}$ soil layers in the different grassland types from 2008 to 2012 ( $M \pm S D$ ). The proportion of the SWS in the different years is labeled with different colors. Different lowercase letters above them indicate significant differences among the means at $p<.05$ in the same year. Different capital letters indicate significant differences among the SWS in the different years of the same grassland type at $p<.05$.

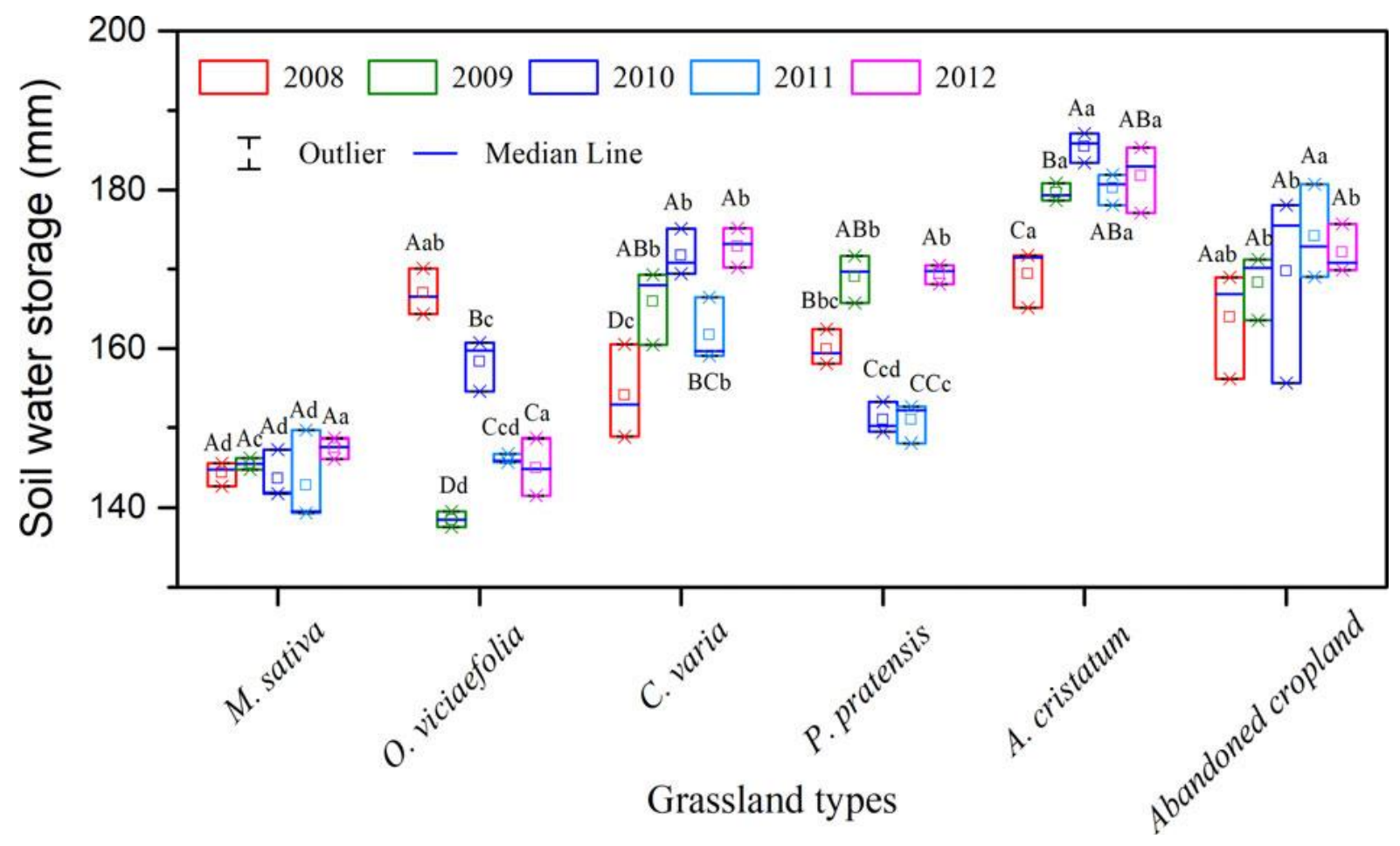


FIGURE 3. Changes of the aboveground biomass (AGB) in the different grassland types from 2008 to $2012(M \pm S D)$. The proportion of the AGB in the different years is labeled with different colours. Different lowercase letters above them indicate significant differences between the means at $p \leq .05$ in the same year. Different capital letters indicate significant differences between the AGB in different years of the same grassland type at $p \leq .05$.

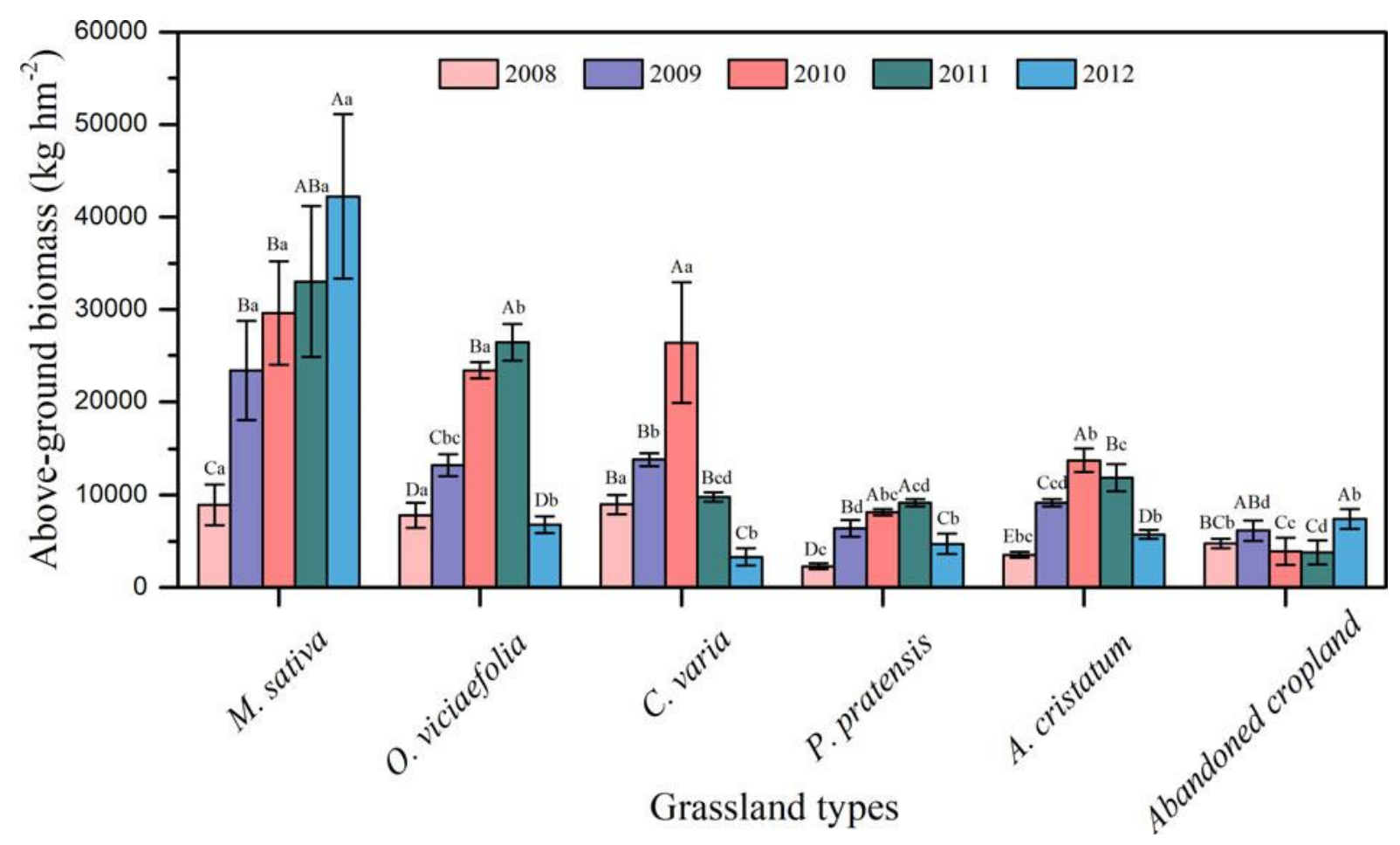


FIGURE 4. Changes of the average aboveground biomass (a) and soil water storage (b) in the different grassland types from 2008 to 2012 (M \pm SD). Different lowercase letters above them indicate significant differences between the means at $p \leq .05$ in the different grassland types.

(a)

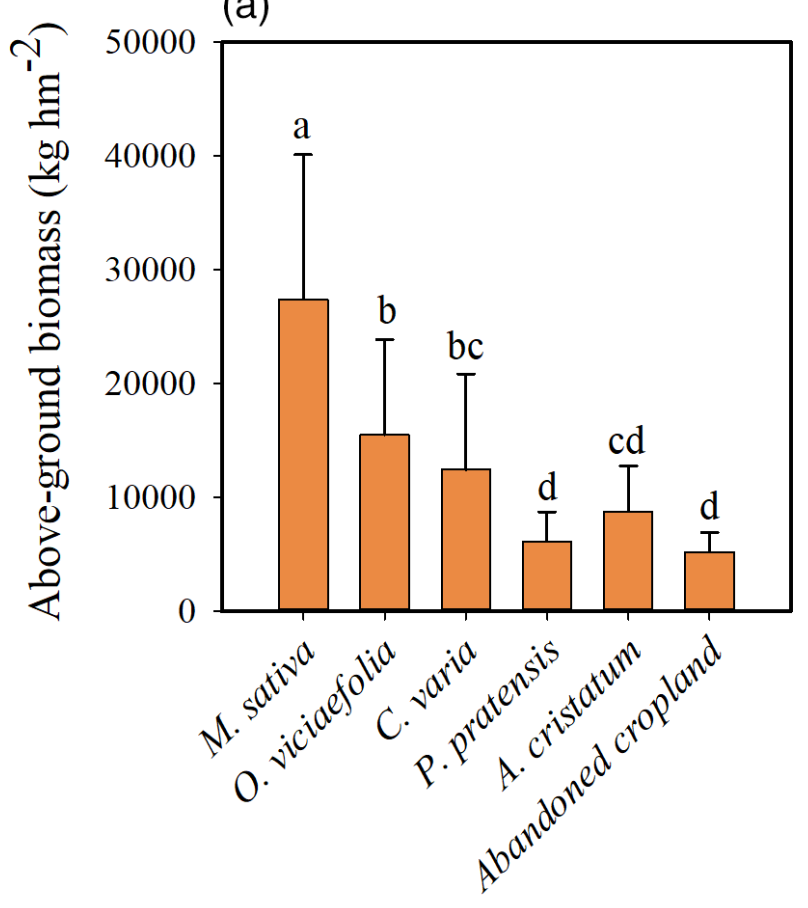

(b)

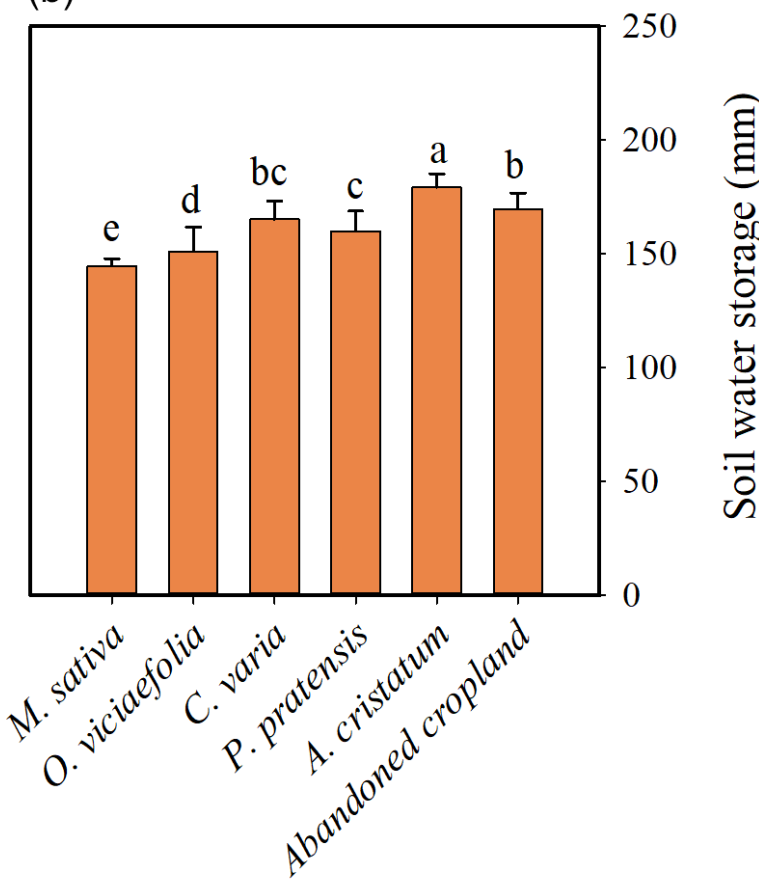

Grassland types 
FIGURE 5. Relationship between the aboveground biomass (AGB) and soil water storage deficit (SWSD) degree (the total of 0 - to 100 -cm soil layers) with the increase of planting years. Yellow line represents SWSD, and blue line represents AGB. The grassland types are A (Medicago sativa), B (Onobrychis viciifolia), C (Coronilla varia), D (Poa pratensis), E (Agropyron cristatum), and F (abandoned cropland).
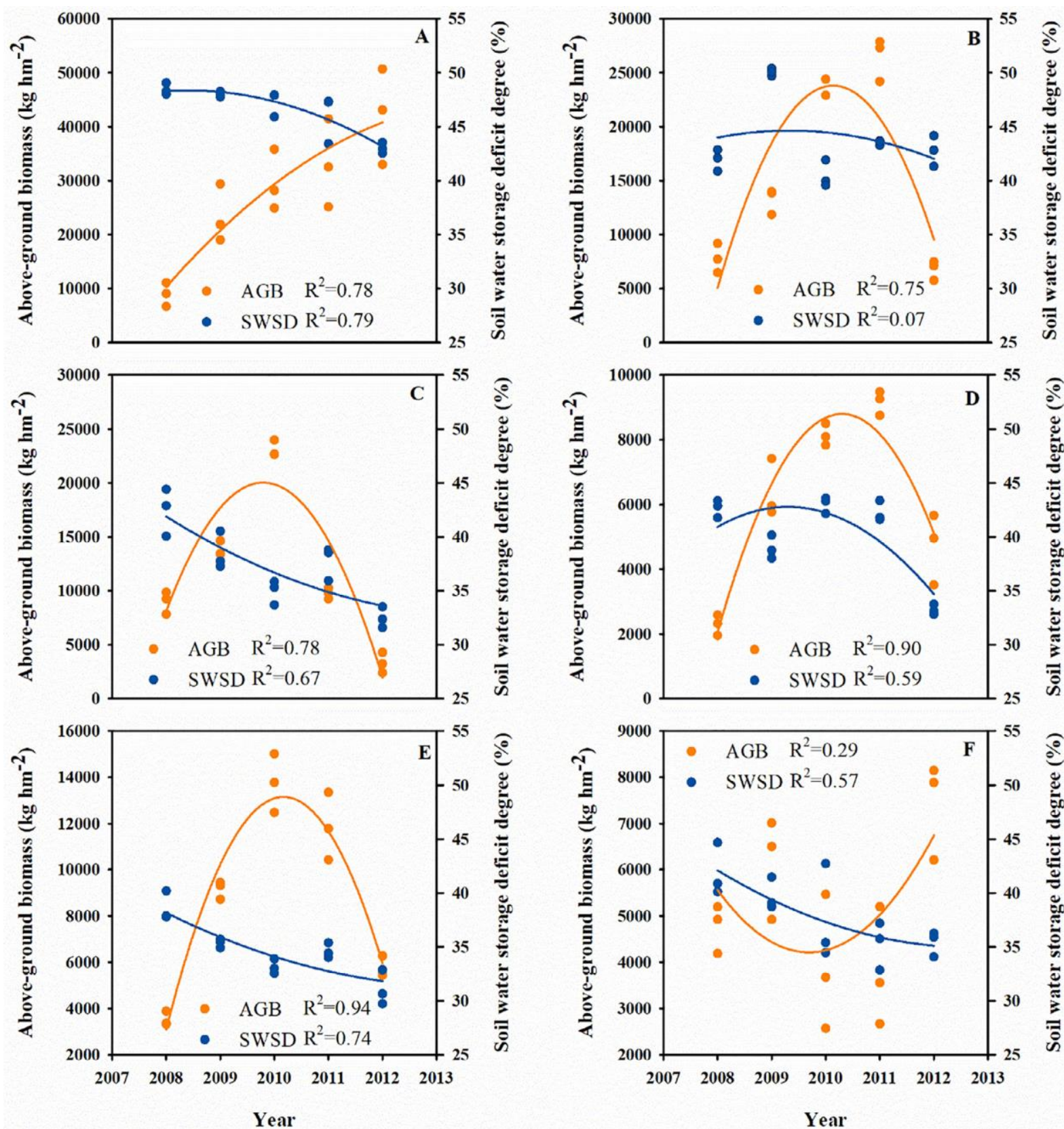
TABLE 1. Results from two-way analysis of variance, testing the effects of planting years, grassland types, and their interaction on soil water storage (SWS) and aboveground biomass (AGB).

\begin{tabular}{|c|c|c|c|c|c|}
\hline Error sources & Num DF & F-value & $P$-value & $F$-value & $P$-value \\
\hline & & SWS & & AGB & \\
\hline Grassland types & 5 & 13.352 & $<0.001$ & 8.235 & $<0.001$ \\
\hline Year & 4 & 0.547 & $>0.05$ & 2.639 & $>0.05$ \\
\hline Grassland types $\times$ Year & 20 & 10.634 & $<0.001$ & 15.779 & $<0.001$ \\
\hline
\end{tabular}

